\title{
Predictors of Violence among Drug Abusers in Selected Drug Joints in Mushin, Lagos Metropolis
}

DOI: https://doi.org/10.47175/rissj.v1i2.46

\section{| Ogunmefun Folorunsho Muyideen |}

\author{
Department of Criminology \\ and Security Studies Chrisland \\ University, Owode, Abeokuta. \\ Ogun State
}

folorunshoogunmefun@gmail.com

\begin{abstract}
The prevailing incidence of illicit drug intake among youths in Nigeria is alarming and undermines developmental structure of the society locally and internationally. All over the world today, cases of Illicit drug consumptions by the Nigeria youths has gained its momentum toward negative directions and its impact has degenerated to series of anti-behavioural problems such as trauma, larceny, egocentric suicide, cybercrime, kidnapping, laziness, terrorism, murdered cases, poor manpower supply and retrogressive national and international images among other nations in the world. Extant publications were reviewed for the study in line with broken theory by Keilling and Wilsons were also adopted for the justification of the inquiry. Mixed method and cross section Survey design and Yemane Yaro formula was adopted to select the 400 respondent for the quantitative inquiry but 245 questionnaires were found useful for the study while 10 in-depth interviews were carried out among the participants. The Chi-square result deciphers that youth access to illicit drug $(X 2)=$ 56.750a; $p<0.005$.) Cost of purchasing of drug $(X 2)=59.598 a, p<$ 0.005.) and nature of employment $(X 2)=46.611, p<0.005$.) of youths has significant relationship with violent behaviour. It is advisable youths to avoid joining drug related gangs; Nigeria Government should be willing to provide basic amenities for the youths so as to reduce violent activities in Nigeria KEYWORDS
\end{abstract}

Substance, abuse; violence; youth; Mushin

\section{INTRODUCTION}

In the world today, the trending issue of illicit drug intake among youths is alarming and it is of great concerns to the societal member. This is because large number of the youths indulged in illicit drugs intake undermining the negative consequences associated with human mental and physical development. Drug use without medical prescription in the developing countries such as African and Asia continents is old as human existence because large number of people in Asia and African continents depends largely on the uses of traditional herbs for self-medication or protection (Odugbemi, 2008). Thus, most western scholars considered self-medication as harmful practices to human physical and mental development because it lacks scientific screening and expiring date. However, in promoting the culture of wellness in any nations, it is the functional responsibility of the state, its apparatus and the entire citizens to fight against illegal means and activities perpetrated in the community especially drug abuse and violent activities among youths (Aborisade, 2016, Ritzer, 2012, Haralambos, Holborn, 2013, Erik et al 2014, Wang, Hipp, Butts, Jose and Lakon, 2015) No wonder scholars such as Nayak (2012), Igbo (2011) and Ajufor (2013)) are of the opinion that youths are the great potentials for driving economic 
growth, good governance and achieving positive political reforms through their participation in labour market and political matters. Therefore, securing the wellness and inculcating quality socialization process among the youths in any nations should be properly researched into because they are catalyst that can sustain societal continuity.

But in recent time in Nigeria, large numbers of the youths are preoccupied with illicit drug intake in different dimension without prescription from the medical experts. However, the causes of this trending and re-occurring decimal such as delinquency or criminal behaviour in the country by the youths are usually related to failure of the families, State government, security apparatus, the medical Association and failure of the entire community members among others (Igwe, Ojinaka, Ejiofor, Emechebe \& Ibe, 2010, Paranjape, 2011, Ninalowo, 2010, Oyekanmi and Soyombo, 2006). But research has shown that scholars are silence on indicators such as demographic, environmental and monetary consequence influencing criminal activity among drug users in Nigeria.

UNODC (2014) asserts that 246 million people (1out of 20 people) between the ages of 15-64 years used an illicit drug in 2013 More so, World Drug Reports (2017) avers that about billions of young people in the entire world today uses illicit drug without medical expert's prescription in 2015 which amounted to 5 per cent of the world population. In addition, about 29.5 million people or 0.6 per cent of the population who used illicit drugs are problematic users and suffered from drug use disorder including dependence and opioids. In relation to Nigeria, the rate at which illicit drugs were marketed, peddled and used by the Nigerian youths in different places, areas or drug joints is worrisome in the country. This is because drugs such as Indian hemp, skunk, codeine, tramadol and refnol among others are commonly accessed on a daily basis, used and very cheap to buy from local peddlers in their various kiosks or shops. In Nigeria, large number of youths uses drugs because they perceived the uses of drugs as stimulant which are commonly sell by local people in shops/kiosk or it may be obtains in different joints on the streets in area such as Alimosho, Agege, Bariga, Somolu, Ajegunle, Boundary, Oshodi, Apapa, Lagos island and Mushin Area of Lagos. However, most of these area mentioned are known to be a crime prone segment of the country and a lot of research needs to be carried out in other to save the lives of the coming generation. In any society, youths easily fall into temptation of youth argot/culture or can easily be influence by a role model or peers either in a positive or negative direction. However, the relevance of the youths in any human society cannot be underrated because they are considered as the innovative brain behind developmental projects of any country. But when their today is preoccupied with the illicit drug intake, they can easily adopt antisocial behaviour as means for survival.

Looking at the modern day Nigeria, most of the antisocial or criminal cases reported through media industries and security agents were carried out by the youths who are expected to be creative and timeless thinking agents in terms of development in the country. In Nigeria, Decker \& Pyrooz (2010) explains that the rate at which Nigerian youths operate in gangs is of great concern, although the act of joining bad gang mostly connotes total destruction in any society. The nexus between illicit drug intake and violent activities among the youths cannot be underestimated. Daniels and Adams (2010) explains that most youth that indulged in violent action are product of extreme poverty, drug abuse, high consumption of alcohol, exclusion, and lack of opportunities, Therefore, one of the major concerns of the family, religious leaders, community elders, the governmental agencies and researchers should be anchored on how to resolve the bi-polar relationship existing between illicit drug intake and criminal activities among the youths all over the world. The relationship has gathered its momentum negating the socio-political, economical, educational and psychological development of any nations facing the 
challenges currently. In Nigeria, several security agencies Nigerian Drug Enforcement Agency with adequate policies and strategies enacted in the past and recent time proved to be weak to fight the menace. However, when these policies failed it will degenerate to delinquency and criminal activities (civil unrest, psychological trauma, vandalization of properties, retrogressive economic turnout and political instability among others) in the country undermining the growth and development of the State. Mostly, youths that engaged in illicit drugs intake such as marijuana, tramadol, codeine, refnor, Alcohol, Cocaine among others are agent of violence or any form of criminal activities in different dimension.

The rate at which the Nigerian youths involve in violent actions is of great concerns and mostly they argued that it is through violent activities they may try to gain their rights and meet their needs by organizing themselves without supervision. More so, they develop their own rules, norms and value which they use as means of security with lot of symbols that gives meaning to their membership in the group. Ellis and Walsh (2010) explain that policing of youths is a very challenging and complex task in any countries in the world. Nayak (2012) explains that it is unfair to generalize and demonize Nigerian youths as violence-prone segment of our population. But in Nigeria undeniable records from different print media shows that a significant proportion of crimes and violent action reported to the security personnel in Nigeria today are mostly carried out by the youth in the country

\section{Objectives Of the Study}

1) To examine the predisposing factors that leads to youth's involvement in the use of illicit drugs

2) To determine the relationship between cost of buying illicit drug and youth involvement in violent action

3) To establish the relationship between the availability of the illicit drug and youth involvement in violent actions

4) To examine the relationship between employment status of illicit drugs users and their involvement in violent actions

\section{Theoretical Framework}

The importance of theories cannot be underrated because it gives room for logical, empirical and systematic approach for explaining, describing, analysing and coming up with predictions that scientifically explains a phenomenon, events or situations. Broken windows theory by Wilson and Keilings (1982) was adopted for the justification of the prevalence of illicit drug intake among the youths in Nigeria. Thus, Wilson and Keiling argued that when minor offences such as delinquent actions or criminal activities noticed in the society by the community members are not reported immediately to the security apparatus on time, such actions or activities will escalate to serious offences or delinquent or criminal activities that will affect the generality of the People. The theory explains that when parents, families and colleagues noticed that young people in the community are taking illicit drugs or ganging up for violent actions such situation should be immediately reported to the security apparatus for immediate check and balances. More so, differential Association by Edwin Sutherland was also adopted because most of the youths that indulged in the use of illicit drugs and criminal activities started from peer influence or learning a particular mode of behaviour or attitude from a role model. Pressure from antisocial relationship gave rise to youth's involvement in illicit drug consumption different countries in the world. The fundamental argument put forwards by the broken 
windows theorists is that failure of the societal members, families, community elders and peer groups in reporting crime on time to the Nigerian security apparatus will lead to antisocial behaviour (delinquency or criminal actions) among the youths while differential association explains reasons for increase in youth involvement in illicit drug use and violent actions in Nigeria While structural functionalist theory asserts that the only way to fight or combat the issue of drug abuse and violence in Nigeria depend largely on the collective responsibility of all the necessary institutions in Nigeria. It is the duty and responsibility of all the institutions such as family, religion organization, health institution, economy institution, political institution and education institution to work hand in hand based on value consensus to fight the menace before it finally get out of control.

\section{RESEARCH METHODOLOGY}

A mixed method (quantitative and qualitative) was adopted in carrying out the inquiry in order to complement the lapses of each method in the inquiry. The quantitative method adopted rely on the use of survey most reliable instrument known structured and unstructured questionnaires to elicit information while the qualitative methods depend largely on the collection of verbal information from the respondents through the use of telecommunication gadget (tape recorder) which was transcribed into a scientific form of analysis. During the research study, Cross sectional research design was adopted for the study because the study research instruments were administered and collected over a short period of time for the research outcome. The study is limited to (4) joints in Mushin Local Government Area of Lagos state where drug users in different joints in Lagos metropolis were interviewed. Therefore, the inclusion and exclusion criteria was adopted to limits the age bracket of the participant over 10yrs-39yrs while less than 10yrs and above 40yrs were excluded. Therefore, the total estimation of the population found appropriate for the inquiry is estimated to 373.481. The breakdown of the research inquiry was drawn from Projected Nigeria Population Census (NPC, 2010) where the estimated for male respondent is estimated to 194.537 while that of the female youth is estimated to 178.944 respondents The sample size was carved out from YemaneYaro (1967) formula $\mathrm{n}=\mathrm{N} /\left(1+\mathrm{N}\left(\mathrm{e}^{\wedge} 2\right)\right.$ ) which gives an estimation of 399 (approximately 400) indicating 208(52\%) sample for male while that of female was at $192(48 \%)$ respondents But the result gathered from the quantitative instrument (questionnaires) after screening coding and editing of the questionnaires out of the four hundred (400) designed only hundred and forty-five (245) were found appropriate for the analysis of the quantitative instruments while out of the twenty (20) qualitative data collected in the different joints (8) eight of the data collected were found useful during the interpretation of the collected raw data in various joints The sampling technique adopted for the study was non-probability sampling technique (purposive sampling technique). Ethical issues such as Informed consent, emotional neutrality, confidentiality among others were highly considered. The use of statistic package for social scientists was adopted for analysing the inquiry using chi-square (SPSS Version 20)

\section{Analysis and Interpretations of Result}

\section{Socio-Demographic Characteristics of Respondents}

The result on the socio-demographic characteristics gathered on the field shows 161 $(65.7 \%)$ of the participants interviewed are male while female constitute 84 (34.3\%). This indicates that majority of the respondents interviewed in different drug joints are male participant On the part of age distribution result shows that $102(41.6 \%)$ of the respondents were within the age bracket of 19-23 years, 89 (36.3\%) of them were within 14-18 years, 
while $54(22.0 \%)$ of them were within 24-29 years. Hence, the table reveals that majority of the respondents that participated in the research inquiry were between age 19-23 years compared to other age ranges. The result on educational background shows that 132 $(53.9 \%)$ of the respondents had Secondary education, 61 (24.9\%) of them had primary school education, $26(10.6 \%)$ of them had no education $24(9.8 \%)$ of them had vocational education, while $2(0.8 \%)$ of the participants had first degree certification in a tertiary. The findings show that over $50 \%$ of the participants interviewed in various drug joints had secondary school certificates. On occupation of the respondents, $136(55.5 \%)$ of the respondents interviewed in various joints claimed to be unemployed, $6124.9 \%$ ) of them are artisan/vocational workers, $23(9.4 \%)$ of the respondents are white collar workers, 21 $(8.6 \%)$ of them are recorded under specify category white $4(1.6 \%)$ of the participants were Blue collar workers. The outcome of the research shows that large numbers of the participants are Unemployed. The result on the drug joints were the interview were carried out indicated that $82(33.5 \%)$ of the participant were interviewed at Head quarter (HQ) at railway line, ilupeju area, $76(31.0 \%)$ of them were interviewed at Akala area of Mushin, $45(18.4 \%)$ of them were interviewed at Ojuwoye market while $42(17.1 \%)$ of them were interviewed at Awolowo market respectively.

Table 1.The table below shows the analysis of the raw data collected from the respondents on their socio-economic characteristics in various drug joints in Mushin Local Government

Area of Lagos state

\begin{tabular}{|c|c|c|c|}
\hline 1 & $\begin{array}{l}\text { Sex of the Respondent } \\
\text { a) Male } \\
\text { b) Female } \\
\text { Total }\end{array}$ & $\begin{array}{c}\text { Frequency } \\
161 \\
84 \\
245\end{array}$ & $\begin{array}{c}\text { Percentage } \\
65.7 \\
34.3 \\
100.0\end{array}$ \\
\hline 2 & $\begin{array}{l}\text { Age Distribution of the Respondents } \\
\text { a) Less than 14years } \\
\text { b) 14-18years } \\
\text { c) 19-23years } \\
\text { d) 24-29years } \\
\text { e) 30-34years } \\
\text { f) 35-39years } \\
\text { Total }\end{array}$ & $\begin{array}{c}- \\
89 \\
102 \\
54 \\
- \\
- \\
245\end{array}$ & $\begin{array}{c}- \\
36.3 \\
41.6 \\
22.0 \\
- \\
- \\
100.0\end{array}$ \\
\hline 3 & $\begin{array}{l}\text { Educational Qualification of the Respon } \\
\text { a) No for Education } \\
\text { b) Primary Education } \\
\text { c) Secondary Education } \\
\text { d) Tertiary Education } \\
\text { e) Vocational Skill } \\
\text { Total }\end{array}$ & $\begin{array}{c}\text { ents Frequency } \\
26 \\
61 \\
132 \\
2 \\
24 \\
245\end{array}$ & $\begin{array}{c}\text { Percentage } \\
10.6 \\
24.9 \\
53.9 \\
.8 \\
9.8 \\
100.0\end{array}$ \\
\hline 4 & $\begin{array}{l}\text { Names of Joints } \\
\text { a) Akala } \\
\text { b) Ojuwoye Market } \\
\text { c) Head Quarter (HQ, Ilupeju) } \\
\text { d) Ladipo Odo } \\
\text { Total }\end{array}$ & $\begin{array}{c}\text { Frequency } \\
76 \\
45 \\
82 \\
42 \\
245\end{array}$ & $\begin{array}{c}\text { Percentages } \\
31.0 \\
18.4 \\
33.5 \\
17.1 \\
100.0\end{array}$ \\
\hline 5 & $\begin{array}{l}\text { Nature of Employment } \\
\text { a) Unemployed } \\
\text { b) White Collar Job } \\
\text { c) Blue Collar Job } \\
\text { d) Artisan/Vocational Job } \\
\text { e) Others Specify } \\
\text { Total }\end{array}$ & $\begin{array}{r}\text { Frequency } \\
136 \\
23 \\
4 \\
61 \\
21 \\
245\end{array}$ & $\begin{array}{r}\text { Percentage } \\
55.3 \\
9.4 \\
1.6 \\
24.9 \\
8.6 \\
100.0\end{array}$ \\
\hline 6 & $\begin{array}{l}\text { Do you know the meaning of Substance } \\
\text { a) Yes }\end{array}$ & $\begin{array}{l}\text { Frequency } \\
201\end{array}$ & $\begin{array}{r}\text { Percentage } \\
82.0\end{array}$ \\
\hline
\end{tabular}




\begin{tabular}{|c|c|c|c|}
\hline & $\begin{array}{cc}\text { b) No } \\
\text { Total }\end{array}$ & $\begin{array}{r}44 \\
245 \\
\end{array}$ & $\begin{array}{r}18.0 \\
100.0 \\
\end{array}$ \\
\hline 7 & $\begin{array}{l}\text { Do you use any substance } \\
\text { a) Yes } \\
\text { b) No } \\
\text { Total }\end{array}$ & $\begin{array}{c}\text { Frequency } \\
198 \\
47 \\
245\end{array}$ & $\begin{array}{r}\text { Percentage } \\
80.8 \\
19.2 \\
100.0\end{array}$ \\
\hline 8 & $\begin{array}{l}\text { How often do you use illicit drug without } \\
\text { Medical expert prescription } \\
\text { a) Daily } \\
\text { b) Weekly } \\
\text { c) Monthly } \\
\text { d) Once with friends } \\
\text { e) No specific Response } \\
\text { Total }\end{array}$ & $\begin{array}{l}\text { Frequency } \\
\qquad \begin{array}{r}124 \\
15 \\
2 \\
62 \\
42 \\
245\end{array}\end{array}$ & $\begin{array}{r}\text { Percentage } \\
50.6 \\
6.1 \\
0.8 \\
25.3 \\
17.1 \\
100.0\end{array}$ \\
\hline 9 & $\begin{array}{l}\text { Cost of Buying the substance } \\
\text { a) Less than N50 } \\
\text { b) N100-N500 } \\
\text { c) N600-N1, 000 } \\
\text { d) N1,001-N1,500 } \\
\text { Total }\end{array}$ & $\begin{array}{l}\text { Frequency } \\
\begin{array}{c}121 \\
93 \\
10 \\
21 \\
245\end{array}\end{array}$ & $\begin{array}{r}\text { Percentage } \\
49.4 \\
38.0 \\
4.1 \\
8.6 \\
90.1\end{array}$ \\
\hline 10 & $\begin{array}{l}\text { Who introduce you to illicit drug intake } \\
\text { a) Through Friends } \\
\text { b) Through Family } \\
\text { c) Through Social Media } \\
\text { d) Personal Curiosity } \\
\text { Total }\end{array}$ & $\begin{array}{c}\text { Frequency } \\
118 \\
11 \\
33 \\
73 \\
245 \\
\end{array}$ & $\begin{array}{r}\text { Percentage } \\
48.2 \\
4.5 \\
17.5 \\
29.8 \\
100.0\end{array}$ \\
\hline 11 & $\begin{array}{l}\text { Which of the substance do you take } \\
\text { a) Marijuana } \\
\text { b) Alcohol } \\
\text { c) Pills (Refnor, Tramador etc) } \\
\text { d) Codeine } \\
\text { e) Skunk } \\
\text { Total }\end{array}$ & $\begin{array}{c}\text { Frequency } \\
102 \\
92 \\
21 \\
- \\
30 \\
245\end{array}$ & $\begin{array}{r}\text { Percentage } \\
41.6 \\
37.6 \\
8.6 \\
- \\
12.2 \\
100.0\end{array}$ \\
\hline 12 & $\begin{array}{l}\text { The use of illicit drug sometime leads to } \\
\text { Violent } \\
\text { a) Yes } \\
\text { b) No } \\
\text { Total }\end{array}$ & $\begin{array}{l}\text { Frequency } \\
\qquad \begin{array}{r}148 \\
97 \\
245 \\
\end{array}\end{array}$ & $\begin{array}{r}\text { Percentages } \\
\qquad \begin{array}{r}60.4 \\
39.6 \\
100.0\end{array}\end{array}$ \\
\hline 13 & $\begin{array}{l}\text { Have you ever indulge in criminal act(s) } \\
\text { a) Yes } \\
\text { b) No } \\
\text { Total }\end{array}$ & $\begin{array}{r}\text { Frequency } \\
47 \\
198 \\
245\end{array}$ & $\begin{array}{r}\text { Percentage } \\
19.2 \\
80.8 \\
100.0\end{array}$ \\
\hline
\end{tabular}

Source; Field Survey, 2019

The result gathered from perception based questions shows that $201(82.0 \%)$ of the participants understood what substance/drug abuse means, while $44(18.0 \%)$ of them claim not to understood what substance/drug abuse means. More so, result from another table deciphers that $198(80.8 \%)$ of the participants in various drug joints uses substance/drug, while $47(19.2 \%)$ of them claimed not to have used any substance/drug. The table above shows that $221(90.2 \%)$ of the participants engaged in illicit drug use without medical expert prescription, while $24(9.8 \%)$ of them claim they cannot use substance /drug without the prescription of an experts. The findings show that large numbers of the participants uses substance without medical prescription. The table above revealed that 102 (41.6\%) of the participants in indulged in the use of Marijuana without medical prescription, 92(37.6\%) of them indulged in the use of alcohol, 30 (12.2\%) of them uses skunk, while 21 $(8.6 \%)$ of them use Pills of different types to stimulate themselves such codeine, tramadol 
and refnor among others Another result indicated that $118(48.2 \%)$ of the participants indulged in the use of substance/drug through friends, 73 (29.8\%) of them through personal curiosity, $30(12.2 \%)$ of them through social media (internet source, films you tube among others), $13(5.3 \%)$ of them said through regular watching of television set and videos, while $11(4.5 \%)$ claimed through some of their family members.. The result of the table on the frequency of use of substance/drug shows that $124(50.6 \%)$ of the participants uses substance/drug without prescription every day or daily, $62(25.3 \%)$ of them use substance/drug once they are with their friends in a social gathering, $42(17.1 \%)$ of them claim that they use substance/drug without any specific interval, $15(6.1 \%)$ of them uses the substance/drug weekly, while $2(0.8 \%)$ of the participants said that they use substance/drug monthly. This shows that large number of the participants in the research inquiry uses substance or drug without medical prescription every day or daily. The result on the cost of buying the substance shows that $121(49.4 \%)$ of the participants revealed that the cost of buying the substance is less than N50, $93(38.0 \%)$ of them said cost of buying the substance is between N100-N500, 21 (8.6\%) of them indicates that the substance cost between $\mathrm{N} 1,001-\mathrm{N} 2,000$, while 10 (4.1\%) of the participants claim the cost of the substance is between $\mathrm{N} 600-\mathrm{N} 1,000$. The information and conclusion derived from the inquiry shows that the buying of the substance is little. Result on another table deciphers that $148(60.4 \%)$ of the participants believe that the use of substance can lead to violence/crime among the users or other people, while $97(39.6 \%)$ of them disagree to the statement. The result gathered on crime shows that $198(80.0 \%)$ of the participants claimed that they have never committed any form of crime before, while 47 (19.2\%) claim that they have committed crime before. The result from the above table shows that quiet a lot of the participants had never commits any form of crime despite the fact that they use substance without medical prescription. The result of the last table deciphers that 192 (78.4\%) of the participants believe that the use of substance/drug increases the tendencies or chances of indulging in violent activities, while $53(21.6 \%)$ of them disagree to the question asked

Table 2. The table deciphers the analysis of the hypothesis tested for the research inquiry. The first hypothesis asserts that the higher the cost of purchasing the substance, the lower the incidence of violent behaviour

\begin{tabular}{|c|c|c|c|}
\hline \multirow{2}{*}{ What is the cost of the substance? } & \multicolumn{2}{|c|}{ Have you ever committed crime } & \multirow[t]{2}{*}{ Total } \\
\hline & Yes & No & \\
\hline Less than N50 & $47(38.8 \%)$ & $74(61.2 \%)$ & $121(100.0 \%)$ \\
\hline N100-N500 & $0(0.0 \%)$ & $93(100.0 \%)$ & $93(100.0 \%)$ \\
\hline N6,000-N1,000 & $0(0.0 \%)$ & $10(100.0 \%)$ & $10(100.0 \%)$ \\
\hline $\mathrm{N} 1,000-\mathrm{N} 2,000$ & $0(0.0 \%)$ & $21(100.0 \%)$ & $21(100.0 \%)$ \\
\hline Total & $47(19.2 \%)$ & $198(80.8 \%)$ & $245(100.0 \%)$ \\
\hline
\end{tabular}

Source; Fieldwork, 2019

The table reveals that the calculated value is $(\mathrm{X} 2)=59.598 \mathrm{a}$ and the " $\mathrm{p}$ " value 0.000 which is less than the level of significance of 0.05 . Thus, we accept the alternative hypothesis (H1) and reject the null hypothesis (H0). Therefore, we can conclude that there is significant relationship between cost of purchasing the drug and tendency to commit a crime The qualitative analysis supported the claim discover in the quantitative analysis where the interviewed respondents

\section{Respondent 1:}

"Cost of buying Indian hemp or cannabis is cheap but like other higher drugs like Cocaine, Heroine, Refnol Codiene among others. I don't indulge in such because i prefer 
to take my cannabis to cool my temper and think about next things to do. The people that take the other drugs are prompt to fight at any time. I am 100\% sure cannabis will not let you go crazy until if witches and wizards of your house are still following the people. I don't me you

IDI/Man W/ Ladipo Joint/29yrs//JSS3 certificate/Ladipo Market/March, 26, 2019.

\section{Respondent 2:}

'Smokers are another set of people in the world to study because they can come to joints without money because they believe that some of their friends will want to share their smoke with them. Buying of smoke is cheap and affordable because how much smoke will you take before you get tired, smoking of Cannabis is still cheap but others pills may be little expensive but cannabis is cheap to buy".

IDI/Lady W/ Akala Joint/29yrs//JSS3 certificate/ Mushin-Idi-oro/ April, 26, 2019.

Table 3. The table below is centered on the test of second hypothesis that asserts that the more youths have access to illicit drug consumption the less likely he or she will indulged in violent action

\begin{tabular}{|c|c|c|c|}
\hline \multicolumn{3}{|c|}{ How often do you use substance without Have you ever committed crime } & \multirow[t]{2}{*}{ Total } \\
\hline medical expert prescription? & Yes & No & \\
\hline Daily & $47(37.9 \%)$ & $77(62.1 \%)$ & $124(100.0 \%)$ \\
\hline Weekly & $0(0.0 \%)$ & $15(100.0 \%)$ & $15(100.0 \%)$ \\
\hline Monthly & $0(0.0 \%)$ & $2(100.0 \%)$ & $2(100.0 \%)$ \\
\hline Only with friends & $0(0.0 \%)$ & $62(100.0 \%)$ & $62(100.0 \%)$ \\
\hline No specific interval & $0(0.0 \%)$ & $42(100.0 \%)$ & $42(100.0 \%)$ \\
\hline Total & $47(19.2 \%)$ & $198(80.8 \%)$ & $245(100.0 \%)$ \\
\hline
\end{tabular}

Source; Fieldwork, 2019

The result in the table shows that there is a significant relationship between the access to the use of substance and youth involvement in criminal activities. Therefore we reject $\mathrm{H}_{0}$ (The Null Hypothesis) and accept $\mathrm{H}_{1}$ (Alternative Hypothesis) which says there is a significant relationship. The qualitative data validated the claims when respondent's interviews indicated that

\section{Respondent 1:}

"I have to tell you the truth sometime if drug joint is very close to you and you are smoking even if you don't have money people will buy for you because if you have money you will always buy for people too. Smokers don't fight, keep malice or be at war with one another unless there is area fight or community supremacy at any corner and it is not regular. People who are not smoking will always say that people that are smoking are bad people but some of them when area fight start you will be surprise that smokers are also bad in their reaction to defend their community. But large number of the people believes that smokers are violent in their ways of doing things"

IDI/Man W/Ladipo Joint/29yrs//JSS3 certificate/Ladipo Market/March, 26, 2019.

\section{Respondent 2 question 3-Answer:}

'Smokers need comfort in all area of lives because after smoking most people will needs to walk down home to relax their mind since there is nothing to do. If joints are closer to drug users it will increase the tendency of smoking more of the substance which might increase the tendency of violent activities'

IDI/Lady W/ Akala Joint/29yrs//JSS3 certificate/ Mushin-Idi-oro /April, 26, 2019. 
Table 4. The table below is centered on the test of hypothesis which states that the less tasking the nature of employment, the more such youths will indulged in violent behaviour

\begin{tabular}{|c|c|c|c|}
\hline \multirow[t]{2}{*}{ Nature of employment } & \multicolumn{2}{|c|}{ Have you ever committed a crime } & \multirow[t]{2}{*}{ Total } \\
\hline & Yes & No & \\
\hline Unemployed & $47(34.6 \%)$ & $89(65.4 \%)$ & $136(100.0 \%)$ \\
\hline White collar & $0(0.0 \%)$ & $23(100.0 \%)$ & $23(100.0 \%)$ \\
\hline Blue collar & $0(0.0 \%)$ & $4(100.0 \%)$ & $4(100.0 \%)$ \\
\hline Artisan & $0(0.0 \%)$ & $61(100.0 \%)$ & $61(100.0 \%)$ \\
\hline Others & $0(0.0 \%)$ & $21(100.0 \%)$ & $21(100.0 \%)$ \\
\hline Total & $47(19.2 \%)$ & $198(80.8 \%)$ & $245(100.0 \%)$ \\
\hline
\end{tabular}

$\mathrm{X}^{2} \mathrm{cal}=46.611^{\mathrm{a}} ; \mathrm{df}=4 ; \mathrm{p}$-value $=0.000$

Source; Fieldwork, 2019

The result in the table shows that there is a significant relationship between the access to the use of substance and youth involvement in criminal activities. Therefore we reject $\mathrm{H}_{0}$ (The Null Hypothesis) and accept $\mathrm{H}_{1}$ (Alternative Hypothesis) which says there is a significant relationship. The qualitative data validated the claims when respondents' interviews indicated that

\section{Respondent 1:}

"I am not a lazy person because if I see work with my little level of education I will work and never remain the same. I finished for Ilaro Poly for Ogun State and I have tried in searching for work and no opportunity but I cannot steal or commit crime that is my main reason for smoking so that I will not thinking about bad things People that indulged in stealing because of money are facing the problem. Please $i$ don't have money or job but $i$ don't want to suffer. I believe that Nigeria will be better one day".

IDI/Lady F Awolowo Joint/25yrs/ND Certificate/Ilupeju/March/November, 16, 2019.

\section{Respondent 2- Answer:}

"Nigeria is a bad country with bad leaders and they want the youths to be good. I have what it takes to be a better person but I don't want to run through trauma I need to cool myself without government interference

IDI/Man X/HQ Joint / 23yrs/Secondary school lever/Ilupeju/ March $162019 .$.

\section{CONCLUSION}

The empirical research inquiry was concluded based on the specific set objectives. Thus, it was concluded that there are several factors that predisposed drug users in violent activities such as peer influence, poverty, seeking for power, recognition, lack of quality education and exposure are parts of the causes of violent in Nigeria among the drug users. Most of the participants indicated that the cost of buying drugs or substance is cheaper and easy to see in their various environments with fewer struggles. Therefore, the situation increases the number of the youths that are coerced to engage in the violent actions other concluded that money or cost of selling drugs cannot stop them from buying it to stimulate their wellbeing while others enjoy the greatness of the drug in their lives. Unemployment situation in Nigeria is one of the major menace that kills or destroy and render most people or especially Nigerians to indulged in substance abuse in the study location Finally the result deduced that the easy access to drug was considered by some youths as alternative for reducing crime rate in their community while others argued that most of the people that indulged in criminal activities in their environment are not based in the area but uses the advantages of the drug joints to perpetrates their hidden motives 


\section{Recommendations}

There are several recommendations that needed to be structured in the country and project effective and efficient ways of eradication or reducing the menace. The recommendations are stated below

1) Everybody or youths must be mentally and physically active and never depends on state security apparatus because they are human being

2) The forming of the community policing should be based on community merits and not just academic merit in providing security for the needy

3) Money should be allocated to medical experts to fight against drug usage, drug control and drug peddling in Nigeria

4) Motivational incentives should be giving to reporters and protect their personality to derived more needed information

5) Drug dealers should be properly dealt with so as to reform their mind set

6) Campaigns, lectures, fora and public announcement should be properly display to increase the level of awareness of the youths.

\section{REFERENCES}

Aborisade, R (2016), Crime and Delinquency; A Sociological Introduction. Oyo State. Ibadan University Press

Adetola, O, Aborisade, R \& Fasanmi, S (2017) Research Methods in Social and Management Sciences (Quantitative and Qualitative Approaches) Ibadan. Ibadan University Press

Ajufor B (2013), Challenges of Youths Unemployment in Nigeria; Effective Career Guidance as a Panacea. African Resource Revision, 7(1)307-321

Daniels, D. \& Adams, Q. (2010) Breaking with Township Gangsterism: The Struggle for Place and Voice, African Studies Quarterly, 11(4) 45-57.

Decker S.H and Pyrooz, D.C (2010), Gang violence across the world in small Arms Survey 2010

Ellis, L \& Walsh, A. (2010) Criminology: A global perspective. Boston: Allyn and Bacon, 107-110.

Erik, R, Merike, S, Air Vamik, P.V, Viadimir, C and Carl, C et al (2014) Alcohol Consumption Patterns among Adolescents are related to family structure and exposure to drunkenness within the family; Result from the SEYLE Project. International Journal of Environmental Research and Public Health 11, 12700-1ies

Haralambos, M \& Holborn, R. M. (2013), Sociology: Themes and Perspectives. London. Harper Collins Publications Limited

Igbo, E. U. M. (2011). Corruption in Nigeria: Patterns and trends. In Alemika, E. E. O., \& Chukwuma, I.C. (Eds.), Criminal victimization, safety and policing in Nigeria (pp. 7186). Lagos: CLEEN Foundation

Paranjape N.V (2011) Criminology and Penology with Victimology. New Delhi. Central Law Publication. India.

Igwe, W.C, Ojinaka, N, Ejiofor, S.O, Emechebe, G.O and Ibe, B.C (2010) Sociodemographic correlates of psychoactive Substance abuse in Enugu, Nigeria. European Journal Social Sciences, 12, 277-283

Nayak, R.C., (2012), Job Challenges and Coping Strategies of Women Police in Orissa: A sociological study in the Twin City of Cuttack and Bhubaneswar, Ph.D Thesis submitted to Utkal University, Bhubaneswar, Onitsha. 
Ninalowo, A, Badru, F and Akinyemi R (2010), An Interdisciplinary Discourse on the Human Condition. Lagos University of Lagos Press

Oyekanmi F and Soyombo O (2006) Society and Governance; The Quest for Legitimacy in Nigeria. Lagos. Friedrich Ebert Stiftung

Ritzer, G. (2012), Modern Theories in Sociology. London. McGraw-Hill Publications Limited

United Nations office on Drugs and Crime(UNODC) World Drug Reports 2017. Geneva, New-York.

Wang C Hipp J.R, Butts, C.T Jose, R \& Lakon C.M (2015), Alcohol use among adolescent youth; The role of friendship Networks and Family factors in Multiple school studies PLOS ONE 0119965, DOI :10.1371/Journal,pone,0119965

World Bank Reports (2013) World Development Indicators, Washington D.C. 2014. 